\title{
Development and Performance Evaluation of Multi Crop Roto Drill cum Herbicide Applicator
}

\author{
Samreen $^{1 *}$, N.V.G. Deekshithulu ${ }^{1}$, B. Raj Kiran ${ }^{1}$, L.R.V. Prasad ${ }^{2}$ and M.V.N. Chaitanya ${ }^{1}$ \\ ${ }^{1}$ College of Agricultural Engineering, Bapatla, A.P., India \\ ${ }^{2}$ University of Wisconsin, Madison, US \\ *Corresponding author
}

\author{
A B S T R A C T
}

\section{Keywords}

Roto drill, Herbicide applicator, Seed drill.

Article Info

Accepted:

07 September 2017

Available Online:

10 November 2017
A tractor drawn roto drill cum herbicide applicator (RDHA) was developed during 201213, at College of Agricultural Engineering, Bapatla. It was developed for adaption of minimum till technology and timeliness of and herbicide application operations. The RDHA was a combination of rotovator, seed hopper (Trough feed type) and rocker sprayer pump. It performs tillage, sowing and herbicide application simultaneously in single pass of tractor. It was found that the total time required for performing the three operations (tillage, sowing and herbicide application) simultaneously with developed RDHA was 3.68 $\mathrm{h} / \mathrm{ha}$ and $4.61 \mathrm{~L} / \mathrm{hr}$ which was $26 \%$ less when compared with the time required for performing the three operations individually. RDHA consumed $17 \%$ more fuel when compared total fuel consumption of individual operations. The RDHA was evaluated for terits seed rate which was observed to be $25.33 \mathrm{~kg} / \mathrm{ha}$ for paddy and $19.02 \mathrm{~kg} / \mathrm{ha}$ for maize. The application rate and spray angle were found to be $321.351 /$ ha and $36.52^{\circ}$ respectively.

\section{Introduction}

Agriculture has witnessed wide variations in growth performance during last decades by introduction of high yielding varieties along with new technologies which enabled the farmers to adopt improved methods of cultivation led to production of higher yields. Although higher yields were produced but cultivation was lagging behind to get considerable amounts of profits this is because of increase in cost of cultivation and agricultural inputs like land, seed, water, labor, fertilizers, pesticides and farm equipment etc., among these there is a drastic increase in cost of labor, fuel and fertilizers which is making agriculture non-economical, unprofitable and unsustainable. Tillage is a major pre-requisite for good yield, apart from this it is a power assisted activity and cost effective. It can account for more than one third of the costs of growing (Arzhang et al., 2006). So, it is important to reduce these costs by adapting minimum tillage.

Reduced tillage not only conserves time and energy but also improves soil environment and increased water availability for plant growth. Next to tillage, sowing is also one of the important operations in crop establishment, which includes timely sowing, accurate and uniform placement of seeds. The 
cost of seeding is also important in order to minimize the cost of cultivation.

After completion of crop establishment phase, crop has to develop the canopy and has to face the critical competition from weeds so weed management is one of the major factors, which affect the crop yield. Uncontrolled weeds cause grain yield reduction up to $76 \%$ under transplanted conditions (Gnanavel et al., 2010). Therefore, timely weed control is imperative for realizing desired level of productivity. So to overcome this problem herbicide application is the popular method adopted. But now a day's application of pre emergence herbicide has become essential part of conservative farming because it controls weeds early in crop life and maximizing crop yield potential, it also knock down the usage of post emergence herbicide.

Considering the importance crop establishment and weed management in mitigating the cost of cultivation a multi crop roto drill cum herbicide applicator (RDHA) was developed by combining three varied machines such as rotovator, seed drill and herbicide applicator or equipment. RDHA performs tillage, sowing and pre-emergence herbicide application simultaneously in single pass of tractor.

\section{Materials and Methods}

The existing rotovator, seed hopper, rocker sprayer and boom assembly were better utilised and combined to develop RDHA. The fabrication details and individual components of the machine were briefly explained below.

\section{Rotovator}

The rotovator is a primary/secondary tillage tool primarily comprising of L-shaped blades mounted on flanges that are affixed to a shaft that is driven by tractor power take off (PTO) shaft. The selected machine consists of Lshaped alloy carbon steel blades and no modification is made to the implement. The type of rotovator used is shown in figure 1 . The attachments such as rotavator, seed drill and rocker sprayer adds some weight to rear side of the tractor. These attachments may lead to the weight transfer from front to rear side during dynamic condition. Proper and necessary attachments were done prior with considering weight transfer.

\section{Seed hopper}

The hopper was made of mild steel sheet and is in trapezoidal shape. Dimensions of the rectangular portion at the top were $92 \mathrm{~cm} \times 29$ $\mathrm{cm}$. The total depth of the hopper was $23 \mathrm{~cm}$. Up to a depth of $14 \mathrm{~cm}$ it resemble as rectangular box there after it slopes inward to a depth of $9 \mathrm{~cm}$. The dimensions of the bottom portion of the hopper were $92 \mathrm{~cm} \times 8$ $\mathrm{cm}$. It consists of 9 seed tubes, and uses trough feed cell type rotors for metering the seed, which is driven by a chain and sprocket mechanism through the ground wheel. The power transmission system consists of 12 and 19 tooth gear and a ground wheel of diameter $46 \mathrm{~cm}$. The hopper has a facility of altering the metering trough cells to suit different kinds of seeds. Seed hopper with adjustable frame is shown in figure 2.

\section{Herbicide applicator}

As the chemicals are highly reactive and corrosive a suitable corrosion resistant material which has good strength was selected for fabricating the pump and spray boom. Since the brass is more resistant to rusting and inert to chemicals than iron, hence pump barrel, pressure chamber and spray boom made from high quality brass was selected.

The pump is a combination of pump barrel and a pressure chamber as shown in figure 3. 
The pump barrel consists of piston or plunger which drives in it, thus sucking the liquid in to the pressure chamber and expelling it through the discharge line. The reciprocating motion of the piston is given through the free wheel (which freely rotates on the shaft) by using combination of crank mechanism through chain and sprocket drive. Volume of the pressure chamber is 1 liter and the stroke length of the piston is $10 \mathrm{~cm}$, which was obtained at every half revolution of free wheel.

The operating pressure of herbicide applicator was measured by using pressure gauge. Since the developed herbicide applicator is not power (PTO) operated. Reciprocating action of piston rod of rocking sprayer takes power form the ground wheel.

It produces its maximum pressure after $53 \mathrm{~m}$ travel i.e. 35.16 revolutions of ground wheel (70.32 no. of strokes). The pressure was measured after reaching its maximum pressure at 35.16 revolutions of ground wheel and was found to be $1.1 \mathrm{~kg} / \mathrm{cm}^{2}$ with flat fan type nozzles.

\section{Furrow openers}

It is made up of mild steel. Furrow opener opens the soil and places the seed at required depth. Each furrow opener has the provision of separate seed delivery and the distance between the furrow openers can be adjustable. Four furrow openers were provided with a spacing of $25 \mathrm{~cm}$. The type of furrow used is shown in figure 4.

\section{Ground wheel}

Two wheels of $46 \mathrm{~cm}$ diameter were used in which one is ground wheel and other is free wheel. Ground wheel is used to give drive to the metering mechanism using chain and sprocket. The purpose selecting this particular ground wheel is to avoid the slip and skid during the operation since it has the extended spokes on its circumference which facilitates better traction as compared with rubber wheels.

Free wheel also resembles a ground wheel which is used for operating the pump and it consists of 36 teeth sprocket, connected to a 13 teeth gear by using chain which is placed over a $3 \mathrm{~mm}$ diameter circular rod of $20 \mathrm{~cm}$ length. The rotary motion of the rod is converted in to reciprocating motion by using L-shaped pin i.e. crank through crank mechanism, as shown in figure 5 thus providing motion to the piston in the barrel.

\section{Development procedure}

The equipment was the combination of rotavator, seed drill and rocker sprayer pump. The machine was fabricated using available materials, techniques and facilities i.e., to combine the three components.

A hollow square angle iron bar of $200 \mathrm{~cm}$ length is mounted behind the rotavator at a height of $50 \mathrm{~cm}$ from the ground level by extending support bars from the rotavator, fastening by nut and bolt arrangement. The two support bars were made up of L-shaped angle iron of $76 \mathrm{~cm}$ length.

A rectangular box of $101 \mathrm{~cm} \times 51 \mathrm{~cm} \times 94 \mathrm{~cm}$ is fabricated by using L- shaped angle iron bars, in which seed hopper is placed. It is provided with a facility of increasing or decreasing the height of the seed hopper. This complete assembly is mounted over the main frame bar.

The pump assembly and the ground wheels are also attached to the main frame bar suitably. Boom is mounted by taking support from the main frame bar and it is having a facility of increasing or decreasing the height 
of the boom with respect to ground level. The schematic layout of roto drill cum herbicide applicator is shown in figure 6 .

\section{Results and Discussion}

RDHA was developed and tested for its field capacity, field efficiency, fuel consumption, seed rate and application rate of herbicide. Developed machine performs the three operations simultaneously to work in single pass of tractor. The details of RDHA are shown in Table 1.

\section{Theoretical field capacity}

Theoretical field capacity of developed machine was calculated in three different trails and its average value was found to be 0.442 ha $/ \mathrm{hr}$. The details of calculations were presented in Table 2.

\section{Actual field capacity}

It is the actual area of coverage by RDHA. It was also calculated in three different trails and its average value was found to be 0.2708 $\mathrm{ha} / \mathrm{hr}$. The details of calculation are shown in Table. 3.

Figure 7 shows the time taken by the operations (tillage, sowing and herbicide application) when performed individually and the time taken by RDHA. It was found that herbicide application took more time than tillage and sowing operations, the total time taken to perform all the three operations separately is found to be 5 hours. The time taken by RDHA to perform all three operations simultaneously is 3.66 hours in single pass of tractor, which is $26 \%$ less when compared with the total time of all the three operations.

Table.1 Details of roto drill cum herbicide applicator

\begin{tabular}{lll}
\hline S.No & Particularities & Specifications \\
\hline 1 & Length $(\mathrm{mm})$ & 1676 \\
2 & Width $(\mathrm{mm})$ & 1760 \\
3 & Height $(\mathrm{mm})$ & 1422 \\
4 & Seed metering mechanism & Trough feed type \\
5 & Herbicide applicator & Rocker sprayer pump (crank mechanism) \\
7 & Nozzle type & Flat fan \\
8 & Number of nozzles & 6 \\
9 & Number of furrow openers & 4 \\
10 & Type of furrow openers & Shovel type \\
11 & Power transmission & Through chain and sprocket for both pump and seed \\
& & metering mechanism \\
12 & Number of ground wheels & 2 \\
13 & Diameter of ground wheels $(\mathrm{mm})$ & 480 \\
\hline
\end{tabular}

Table.2 Field trials for theoretical field capacity

\begin{tabular}{cccc}
\hline Trail & Speed of operation $(\mathbf{k m} / \mathbf{h r})$ & Operating width $\mathbf{( m )}$ & Theoretical field capacity (ha/hr) \\
\hline 1 & 2.690 & 1.53 & 0.411 \\
2 & 3.098 & 1.53 & 0.473 \\
3 & 2.894 & 1.53 & 0.442 \\
Average & 2.894 & 1.53 & 0.442 \\
\hline
\end{tabular}


Table.3 Field trials of actual field capacity

\begin{tabular}{ccc}
\hline Trail & $\begin{array}{c}\text { Time taken to cover an area of 1000 } \\
\mathbf{m}^{\mathbf{2}} \text { in } \mathbf{~ m i n}\end{array}$ & Actual field capacity, ha/hr \\
\hline 1 & 22.15 & 0.270 \\
2 & 21.10 & 0.258 \\
3 & 23.20 & 0.258 \\
Average & 22.15 & 0.271 \\
\hline
\end{tabular}

Table.4 Discharge rate of nozzles

\begin{tabular}{cc}
\hline Nozzle & Discharge (ml/min) \\
\hline 1 & 455 \\
2 & 465 \\
3 & 480 \\
4 & 475 \\
5 & 450 \\
6 & 460 \\
Total discharge/ min & 2325 \\
\hline
\end{tabular}

Table.5 Details of seed rates and calibration of roto drill cum herbicide applicator

\begin{tabular}{|c|c|c|c|}
\hline S.No & Particulars & Maize & Paddy \\
\hline 1 & Type of metering mechanism & Trough feed & Trough feed \\
\hline 3 & No of tynes & 4 & 4 \\
\hline 4 & Diameter of ground wheel & $\begin{array}{l}48 \mathrm{~cm} \text { (inner dia: } 38.5 \mathrm{~cm} \text {, peg } \\
\text { height: } 9 \mathrm{~cm} \text { ) }\end{array}$ & $\begin{array}{l}48 \mathrm{~cm} \text { (inner dia: } 38.5 \\
\mathrm{~cm} \text {, peg height: } 9 \mathrm{~cm} \text { ) }\end{array}$ \\
\hline 6 & $\begin{array}{l}\text { No. of ground wheel } \\
\text { revolutions have to be made to } \\
\text { cover } 1 / 25^{\text {th }} \text { ha }\end{array}$ & 130.5 say 130 & 130.5 say 130 \\
\hline 7 & $\begin{array}{l}\text { Area covered for } 130 \\
\text { revolutions of the ground wheel }\end{array}$ & $398.32 \mathrm{~m}^{2}$ & $398.32 \mathrm{~m}^{2}$ \\
\hline \multirow[t]{4}{*}{8} & Seed collected from tubes after & Tube $1: 243 \mathrm{~g}$ & Tube $1: 183 \mathrm{~g}$ \\
\hline & 130 revolutions of the ground & Tube $2: 240 \mathrm{~g}$ & Tube $2: 183 \mathrm{~g}$ \\
\hline & wheel & Tube $3: 260 \mathrm{~g}$ & Tube $3: 196 \mathrm{~g}$ \\
\hline & & Tube $4: 266 \mathrm{~g}$ & Tube $4: 196 \mathrm{~g}$ \\
\hline 9 & $\begin{array}{l}\text { Total seed collected for } 130 \\
\text { revolutions }\end{array}$ & $1009 \mathrm{~g}$ & $758 \mathrm{~g}$ \\
\hline 11 & For 1 acre total seed & $10.225 \mathrm{~kg}$ & $7.70 \mathrm{~kg}$ \\
\hline 12 & Seed rate & $25.331 \mathrm{~kg} / \mathrm{ha}$ & $19.029 \mathrm{~kg} / \mathrm{ha}$ \\
\hline
\end{tabular}


Table.6 Details of fuel consumption for individual operations and combined operation

\begin{tabular}{llll}
\hline S.No & Operation & Equipment & $\begin{array}{l}\text { Amount of fuel consumed } \\
\text { for operation (L/ha) }\end{array}$ \\
\hline 1 & Tillage & Tractor + Rotovator & 6.07 \\
2 & Sowing & Tractor + Seed drill & 6.83 \\
3 & Herbicide application & Knapsack sprayer & 1.248 \\
& $\begin{array}{l}\text { Tillage, sowing and pre- } \\
\text { emergence herbicide }\end{array}$ & $\begin{array}{l}\text { Tractor + Roto drill cum } \\
\text { herbicide applicator }\end{array}$ & 17 \\
& application simultaneously & . & \\
\hline
\end{tabular}

Fig.1 Rotovator

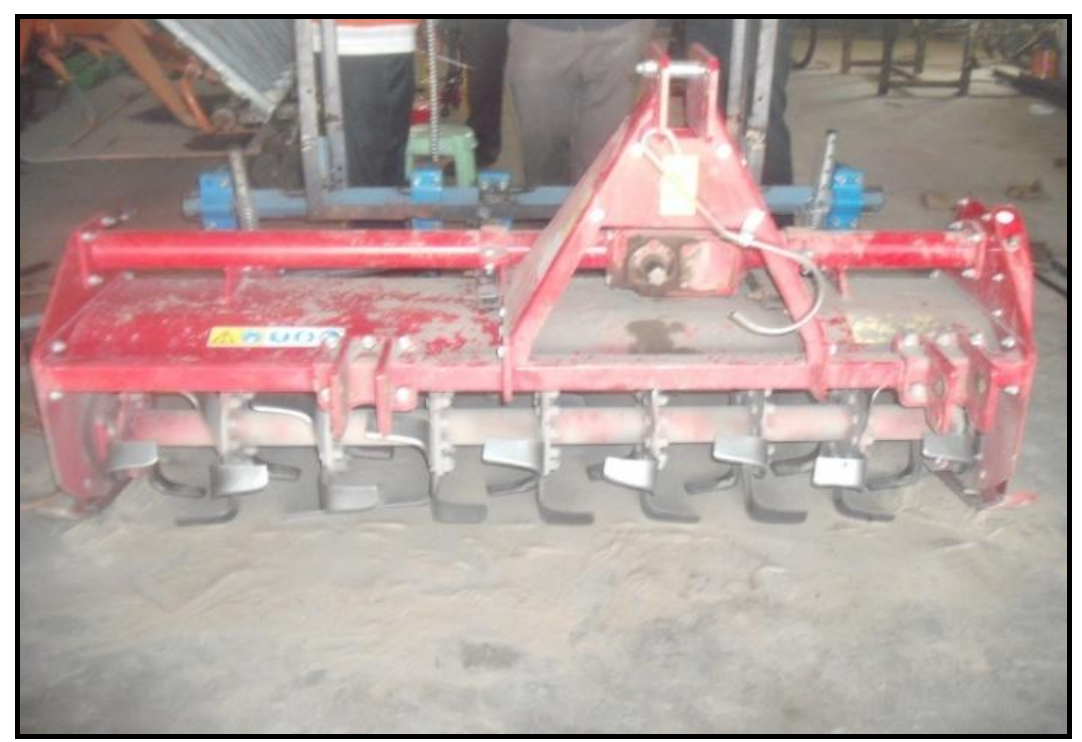

Fig.2 Seed hopper

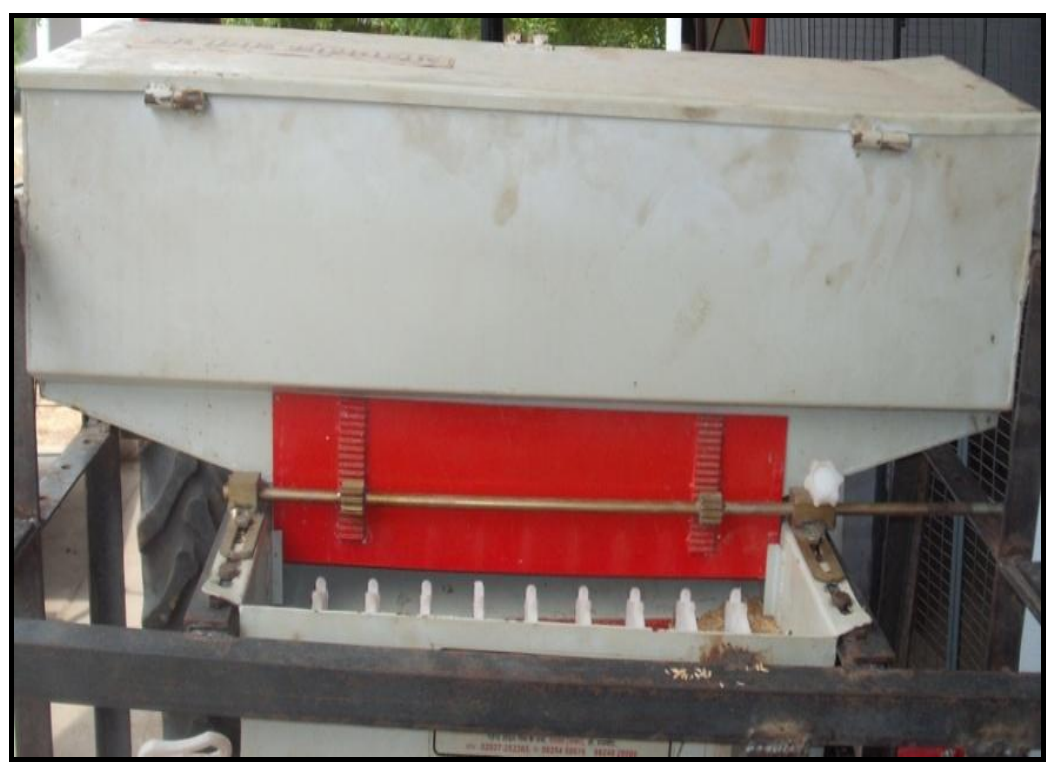


Fig.3 Pump barrel of herbicide applicator

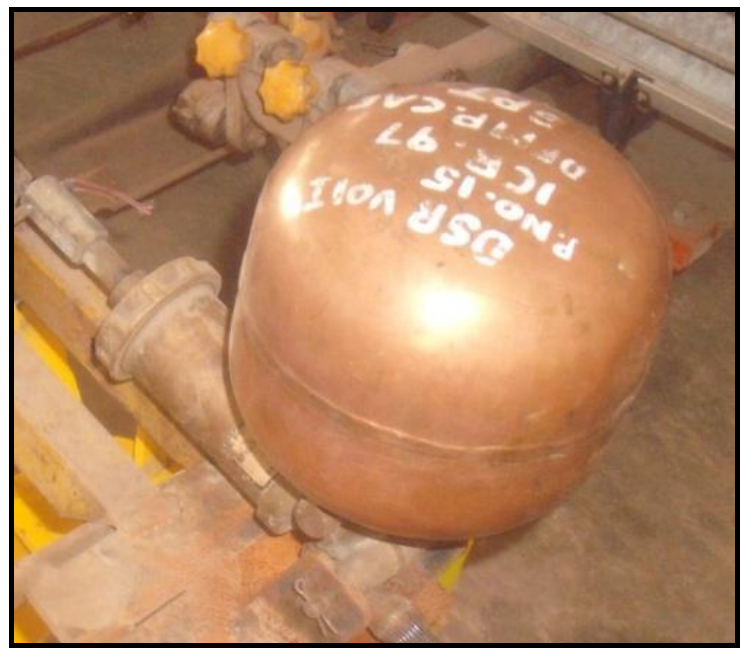

Fig.4 Shovel type furrow opener

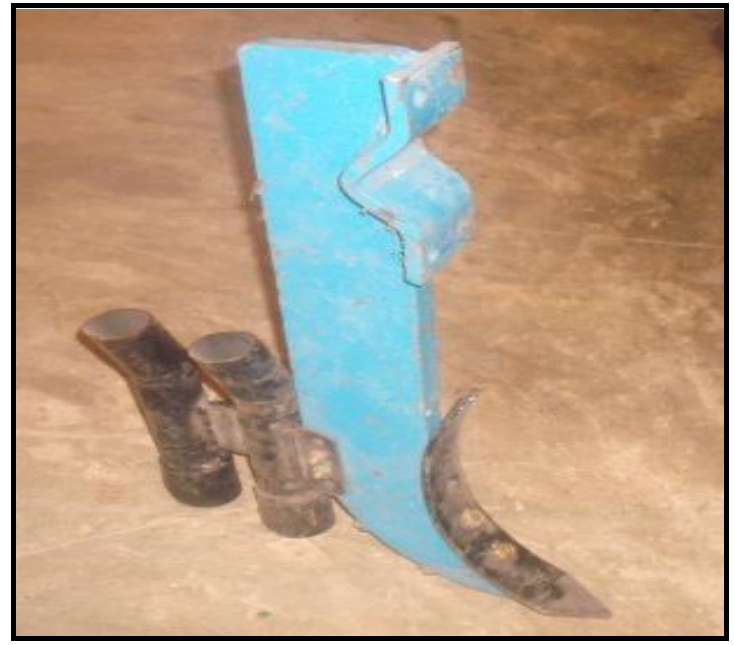

Fig.5 Ground wheels attachment

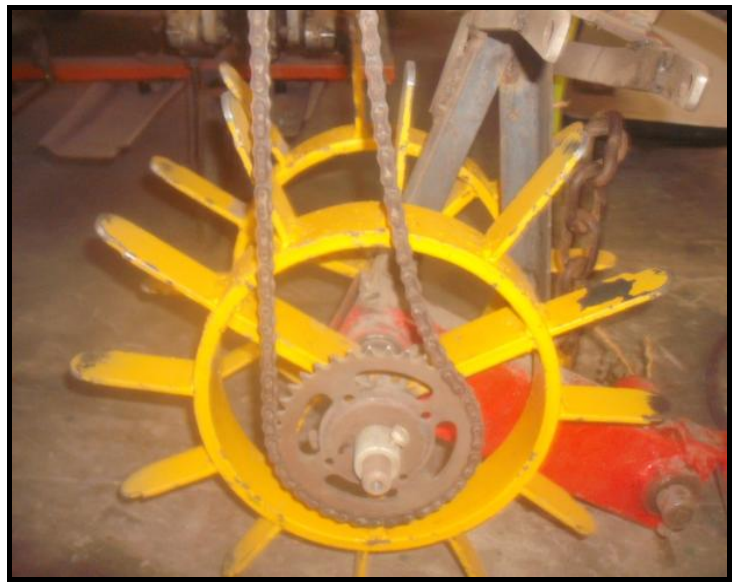


Fig.6 Roto drill cum herbicide applicator

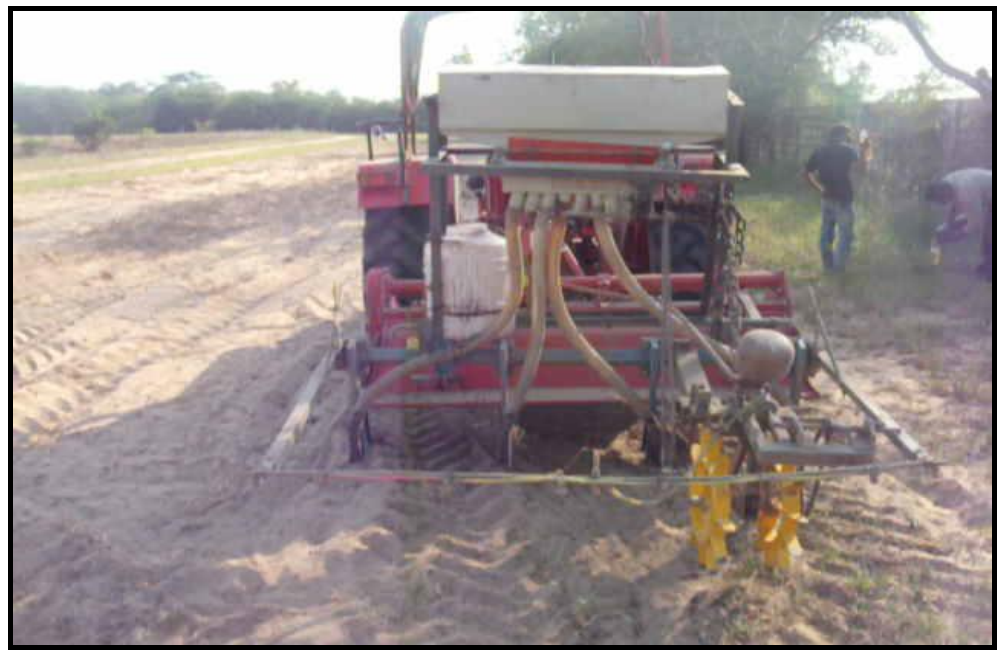

Fig.7 Time taken by individual operations and in roto drill cum herbicide applicator

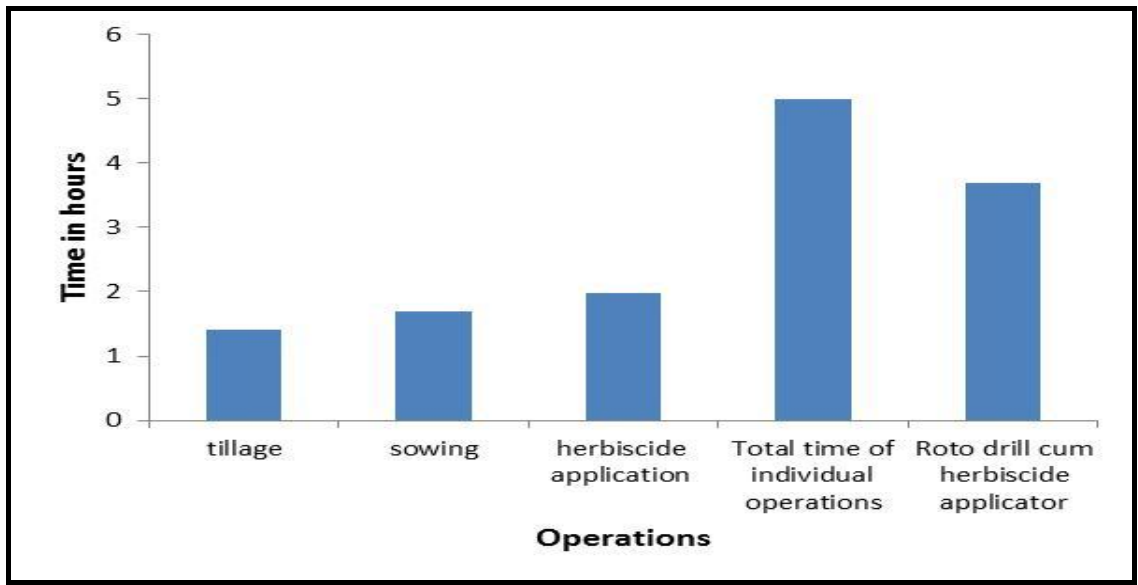

From the observations recorded in the field it was revealed that the actual field capacity and field efficiency of the RDHA was $0.2708 \mathrm{ha} / \mathrm{hr}$ and $61 \%$ respectively. The seed rate of the machine was calculated for paddy and maize according to Indian standards both in laboratory and field conditions. The discharge rate of herbicide applicator was measured by collecting the test liquid from each nozzle in catch cans for one minute and it was measured by using measuring cylinder. It was observed that the discharge rate of herbicide applicator was 2.325 $\mathrm{L} / \mathrm{min}$. The details of discharge at each nozzle are given in Table 4 and the application rate of the machine was $321.35 \mathrm{l} / \mathrm{ha}$. The seed rate achieved for paddy and maize was 19.0 and
$25.3 \mathrm{~kg} / \mathrm{ha}$ respectively. The details of calibration were shown in Table 5.

\section{Fuel consumption}

Table 6 presents the details of fuel consumption for individual operations and roto drill cum herbicide applicator as well. $14 \mathrm{~L}$ of fuel was consumed per hectare area when tillage, sowing and herbicide application operations were performed individually whereas roto drill cum herbicide applicator consumed $17 \mathrm{~L}$ of fuel per hectare area for performing all the three operations simultaneously. It was found that roto drill cum herbicide applicator consumed $17 \%$ more fuel when compared with total fuel 
consumption of individual operations.

The testing revealed that the developed machine gave the better performance than the conventional methods of tillage, sowing and herbicide application. Theoretical and actual field capacity were found to be $0.442 \mathrm{ha} / \mathrm{hr}$ and $0.278 \mathrm{ha} / \mathrm{hr}$ with an efficiency of $61 \%$ and it can save substantial amount of time by performing the operations simultaneously in single pass of tractor. It can be used for sowing most of the seeds by simply altering the metering cells. Finally the developed machine can be adopted as a wise substitute for conventional methods so that time and labor can be saved.

\section{References}

Arzhang, J and Ali, H. 2006. Effect of new combined implement for reducing secondary tillage operation. International Journal of Agriculture and Biology. 724727.

Ejaz, K., Tahir, A.B, Khan, F. and Tariq, M. 2004. Performance evaluation of modified self-leveling boom sprayer. International journal of agriculture and biology. 636-638.

Gnanavel, I. and Anbhazhagan, R. 2010. Bioefficacy of pre and post-emergence herbicides in transplanted aromatic basmati rice. Research Journal of Agricultural Sciences. 1(4): 315-317.

Gupta, R.A., Mohnot, P., Satasiya, R.M. and Marvia, R.B. 2004. Development and testing of a seed-cum-fertilizer drilling attachment to tractor-driven cultivator. Agricultural Mechanization in Asia, Africa and Latin America. 35(2): 15-20.

Maheshwari, T.K., Verma, M.R and Kumar, D. 2006. Performance Study of multicrop seed cum ferti Drill. Agricultural
Engineering Today. 30(1-2): 23-27.

Nadiger. S., Babu, R and Aravindkumar, B.N. 2013. Bio-efficacy of pre-emergence herbicides on weed management in maize. Karnataka journal of agriculture sciences. 26(1): 17-19.

Padmanathan, P.K and Kathirvel, K. 2007. Performance evaluation of power tiller operated rear mounted boom sprayer for Cotton Crop. Research Journal of agriculture and biological sciences. 3(4): 224-227.

Patel, S.K and Varshney, B.P. 2007. Coefficient of uniformity of an experiment plot drill for different seed. Journal of Agriculture Engineering. 44(3): 20-24.

Pathak, H., Antewari, Sankhyan, S., Dubey. D.S., Mina, U., Singh, V.K., Jain, N and Bhatla, A. 2011. Direct seeded rice: Potential, performance and problems - A review. Current advances in agricultural sciences. 3(2): 77-88.

Shrivatsava, A.K and Jha, S. 2011. Modification and performance evaluation of tractor drawn improved till plant machine under vertisol. Agricultural Engineering Journal: the CIGR journal. 13(2).

Singh, S and Verma, S.R. 2009. Farm machinery maintenance and management. Directorate of information and publications of Agriculture. 150-151.

Verma, A.K and Dewangan, M.L. 2007. Design, development and evaluation of seed cum fertilizer Drill. Agricultural mechanization in Asia, Africa and Latin America. 38(2): 33-38.

Yasin, M and Yasin, M.A. 2009. Design, development and performance evaluation of rota drill. Agricultural mechanization in Asia, Africa and Latin America. 40(3): $39-40$.

\section{How to cite this article:}

Samreen, N.V.G. Deekshithulu, B. Raj Kiran, L.R.V. Prasad and Chaitanya, M.V.N. 2017. Development and Performance Evaluation of Multi Crop Roto Drill cum Herbicide Applicator. Int.J.Curr.Microbiol.App.Sci. 6(11): 522-530. doi: https://doi.org/10.20546/ijcmas.2017.611.063 